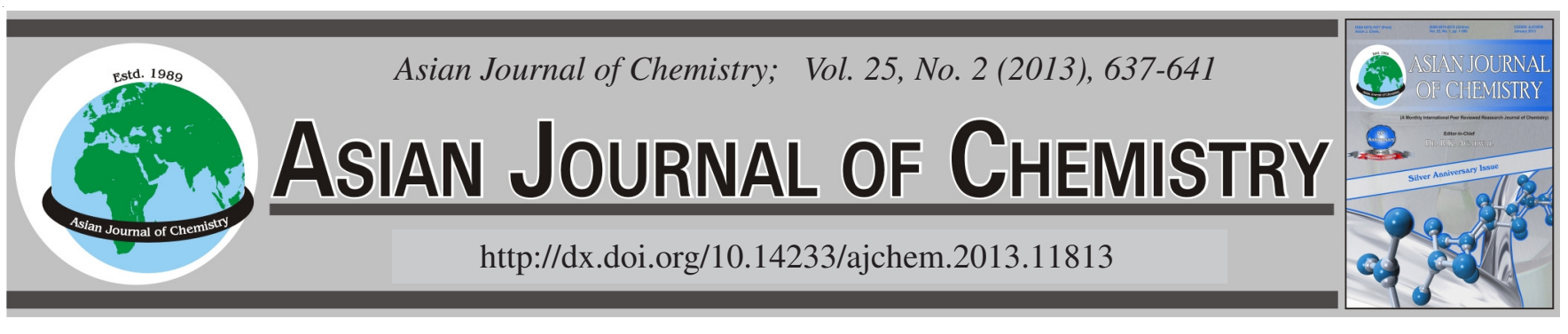

\title{
Effects of Chemical Modifications on Mechanical Properties of Luffa cylindrica
}

\author{
D. $\operatorname{KOCAK}^{1}$, N. MERDAN ${ }^{2}$, M. YUKSEK ${ }^{1}$ and E. SANCAK ${ }^{1, *}$
}

${ }^{1}$ Textile Department, Technical Education Faculty, Marmara University, Göztepe, Istanbul, Turkey

${ }^{2}$ Design Department, Faculty of Engineering, Istanbul Commerce University, 34840 Küçükyalý, Istanbul, Turkey

*Corresponding author: E-mail: esancak@marmara.edu.tr

(Received: 12 February 2011;

Accepted: 9 August 2012)

AJC-11945

\begin{abstract}
Among the natural fibres, Luffa cylindrica fibres are the ones that are widely available throughout the world. Luffa fibres are known to have lignocellulosic fibre characteristics. Depending on their use, there is work to make them more useful by means of chemical processes. For this aim, through two different processes, conventional and microwave, three different chemical processes were applied. The results obtained were examined with \% weight loss values; mechanical properties, morphological characteristics (SEM) followed by FT-IR and $\mathrm{X}$-ray diffraction properties. Three different processes chemical processes, carried out with formic acid and acetic acid were proved to be successful. The reason for the microwave processes to be successful is the strength achieved by sonication. In this study, formic acid and acetic acid processes were found to adequately modify the fibres surfaces.

Key Words: Biofibers, Chemical treatment, Luffa cylindrica, Microwave energy.
\end{abstract}

\section{INTRODUCTION}

The use of cellulosic or lignocellulosic materials (cellulose fibers, wood fibers, nut flour, jute, sisal, etc.) as filler for reinforcement of polymeric matrices has increased lately. They are rich in lignin, hemicellulose and cellulose and are used for various applications depending on their composition and physical properties. An increasing world trend towards the maximum utilization of natural resources through new processes and products has been driving to the study and exploration of rich renewable natural materials generating new applications to lignocellulosic fibers in the automotive industry, production of adhesives, lactic acid, active carbon and furfural $^{1,2}$ in the development of composites. Apart from the well-known fibers (flax, ramie, jute, etc.) one of the most interesting among the lesser known fibers is the luffa cylindrical fiber.

This fiber is quite common in the mid-south of America as well. As for Turkey, it grows well in the areas of the Mediterranean climate. The Luffa cylindrica fibers are a subtropical plant of the cucurbitaceous family, which produces a fruit with a fibrous vascular system. Their size varies in relation to the areas they grow in ranging from $15 \mathrm{~cm}$ to1m, or even more than one meter in certain kinds ${ }^{3}$ (Fig. 1). It has wide use of Luffa cylindrica as scouring pads during bathing, for the manufacture of palm sole, inner soler for filters, leather straps for automobiles and other engine, etc. in the industrial sector ${ }^{4}$.
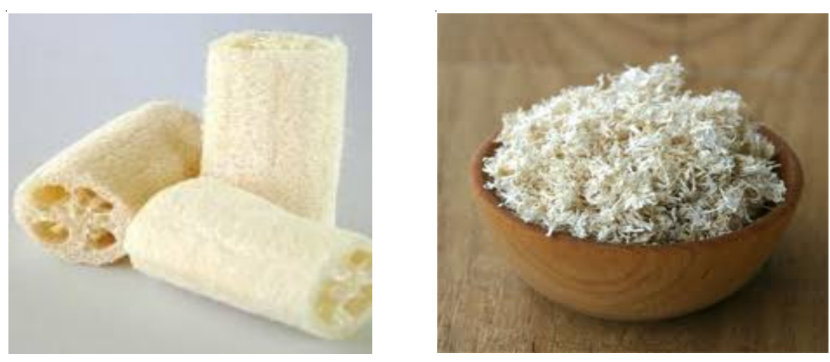

Fig. 1. Luffa fibres

A number of investigatators have explored the capability of additives to enhance adhesion and thereby improve properties, such as tensile, impact and flexural strengths of these composite materials ${ }^{5,6}$. The methods for surface modification can be physical or chemical according to the way they modify the fiber surface frequently used approaches are bleaching, acetylation and alkali treatments.

When the chemical characteristics of Luffa cylindrica are considered, it can be seen that just in the case of such fibers as manila, sisal, jute, hemp, they consist of cellulosic polymer that are composed of various non-cellulosic impurities that do not affect the hydrophilic characteristic of Luffa cylindrica fibers negatively (Table-1) ${ }^{7}$.

For this purpose, the studies carried out to improve the hydrophilic characteristic of Luffa cylindrica by means of chemical processes. With this aim, mercerization was applied 
TABLE-1

CHEMICAL COMPOSITION OF Luffa cylindrica FIBRES

\begin{tabular}{lc} 
Component & Content $(\%)$ \\
\hline Holocellulose & 82.4 \\
$\alpha$-Cellulose & 63.0 \\
Hemicellulose & 19.4 \\
Lignin & 11.2 \\
Extractives & 3.2 \\
Ashes & 0.4
\end{tabular}

on Luffa cylindrica fibers ${ }^{8}$, by acetylating derivation was achieved ${ }^{9}$. In addition to this, anion exchange capacity of $L u f f a$ cylindrica fibers and their quaternizated specialties were tested ${ }^{10}$. Luffa cylindrica fibers were coated with different kinds of tip silane agent in order to improve the characteristics of the composite produced from $\mathrm{LF} / \mathrm{PP}^{11}$. Most of these studies are based on cleaning those impurities affecting the mechanical, chemical, physical and sorption characteristics of Luffa cylindrica fibers.

Ultrasonic energy has always been an alternative method. The action of ultrasound energy has become popular in textile sector with positive results in bleaching and dying processes ${ }^{8-14}$.

Cavitation is the formation and violent collapse of small bubbles or voids in the liquid as a result of pressure changes. This occurs when longitudinal waves propagate through the liquid. Cavitations cause several chemical and mechanical effects, such as dispersing, degassing, formation of free ions or radicals and intense agitation of the liquid ${ }^{13}$. When the microwaves become $13.56,27.12$ and $40.68 \mathrm{MHz}$ at region of $\mathrm{RF}$ which are industrial frequency, the frequency ranges are between 910-2850 MHz for the MD. Using of microwave technology in textile finishing is related with application, research and development studies which enclose application areas of heating up, drying, condensation, dying and printing ${ }^{15-20}$.

In this study, three processes in conventional, ultrasonic energy and microwave energy were applied on Luffa cylindrica fibers and three different chemical treatments (acidic acid and formic acid) have been performed. The mechanical, hydrophilic, thermal and morphological characteristics of Luffa cylindrica fibres were also reported.

\section{EXPERIMENTAL}

Luffa cylindrica fibres were obtained from the Mediterranean region of Turkey. Its fruit has a fibrous vascular system that forms a natural mat when dried. Their overall lengths were between 400 and $600 \mathrm{~mm}$. The luffa fibres were washed with water to remove the adhering dirt for $0.5 \mathrm{~h}$ at $20^{\circ} \mathrm{C}$ with distilled water. They were dried in an oven $6 \mathrm{~h}$ at $70^{\circ} \mathrm{C}$. After drying, they were conditioned for $48 \mathrm{~h}$ prior to testing under \pm $20^{\circ} \mathrm{C}$ and $65 \pm 2 \mathrm{RH} \%$ condition.

Chemical treatments of luffa fibers treatments: Luffa fibers have been characterized by three methods in which are given conventional methods, ultrasonic methods and microwave methods (Tables 2-4). In addition to that, it is applied two kind of chemical process for each three methods. Ultrasonic method Branson B2200B E4 was carried out at (220 volt and 205 watt) ultrasonic bath with $20 \mathrm{kHz}$ frequencies.

Microwave method with a Galanz/WP800T was carried out at a frequency of $2.45 \mathrm{GHz}$. The microwave oven had a maximal power of $800 \mathrm{~W}$ with six discrete settings. The mixtures were placed in a sealed glass vessel and treated by the microwave according to the experimental design.

Analytical methods: The weight loss was determined on atmospherically conditioned luffa fibres after different pretreatment processes, with and without ultrasound. The weight loss percentage $\left(\mathrm{W}_{\mathrm{i}}\right)$ was calculated from the differences in weight using the following equation (eqn. 1);

$$
\mathrm{W}_{\mathrm{i}}=\frac{\mathrm{W}_{\text {pre }}-\mathrm{W}_{\mathrm{after}}}{\mathrm{W}_{\text {pre }}} \times 100 \%
$$

where $\mathrm{W}_{\text {pre }}$ is the weight of the conditioned fibres prior to pretreatment and $\mathrm{W}_{\text {after }}$ is the weight after performed pretreatment. Following the conventional ultrasonic method and microwave methods, Luffa cylindrica fibre's which property is given in Table-1.

Testing and characterization of Luffa cylindrica fibres after chemical treatments: Applying the conventional, micro wave and ultrasonic energy methods on Luffa cylindrica fibres (single fibres length $10 \mathrm{~mm}$ ) mechanical characteristic

\begin{tabular}{|c|c|c|c|c|c|c|c|}
\hline \multicolumn{8}{|c|}{$\begin{array}{c}\text { TABLE-2 } \\
\text { CONVENTIONAL METHODS APPLIED }\end{array}$} \\
\hline $\begin{array}{l}\text { Conventional } \\
\text { methods }\end{array}$ & $\begin{array}{c}\text { Solution } \\
\text { (chemicals) }\end{array}$ & Producer/supplier & $\begin{array}{l}\text { Conc. } \\
(\%)\end{array}$ & $\begin{array}{l}\text { Temp. } \\
\left({ }^{\circ} \mathrm{C}\right)\end{array}$ & $\begin{array}{l}\text { Time } \\
(\min )\end{array}$ & $\begin{array}{c}\text { Rinsed process } \\
\left(25^{\circ} \mathrm{C}, 10 \mathrm{~min}, \mathrm{pH} 7\right)\end{array}$ & Dry process \\
\hline Method 1 & Formic acid & Merck (100263) & 99 & 20 & 40 & Distilled water & At room temperature \\
\hline Method 2 & Acetic acid & Merck (109944) & 100 & 40 & 40 & Distilled water & At room temperature \\
\hline
\end{tabular}

\begin{tabular}{cccccccc}
\multicolumn{7}{c}{ TABLE-3 } \\
ULTRASONIC ENERGY METHODS APPLIED TO Luffa cylindrica FIBERS \\
\hline $\begin{array}{c}\text { Ultrasonic } \\
\text { methods }\end{array}$ & $\begin{array}{c}\text { Solution } \\
\text { (chemicals) }\end{array}$ & Producer/supplier & $\begin{array}{c}\text { Conc. } \\
(\%)\end{array}$ & $\begin{array}{c}\text { Temp. } \\
\left({ }^{\circ} \mathrm{C}\right)\end{array}$ & $\begin{array}{c}\text { Time } \\
(\mathrm{min})\end{array}$ & $\begin{array}{c}\text { Rinsed process } \\
\left(25^{\circ} \mathrm{C}, 10 \text { min, } \mathrm{pH} 7\right)\end{array}$ & Dry process \\
\hline Method 1 & Formic acid & Merck $(100263)$ & 99 & 20 & 40 & Distilled water & At room temperature \\
Method 2 & Acetic acid & Merck $(109944)$ & 100 & 25 & 40 & Distilled water & At room temperature \\
\hline
\end{tabular}

\begin{tabular}{cccccccc}
\multicolumn{8}{c}{ TABLE-4 } \\
\hline $\begin{array}{c}\text { Micro wave } \\
\text { methods }\end{array}$ & $\begin{array}{c}\text { Solution } \\
\text { (chemicals) }\end{array}$ & Producer/supplier & $\begin{array}{c}\text { Conc. } \\
(\%)\end{array}$ & $\begin{array}{c}\text { Temp. } \\
\left({ }^{\circ} \mathrm{C}\right)\end{array}$ & $\begin{array}{c}\text { Time } \\
(\mathrm{min})\end{array}$ & $\begin{array}{c}\text { Rinsed process } \\
\left(25^{\circ} \mathrm{C}, 10 \text { min, } \mathrm{pH} \text { 7) }\right.\end{array}$ & Dry process \\
\hline Method 1 & Formic acid & Merck $(100263)$ & 99 & 20 & 40 & Distilled water & $\begin{array}{c}\text { At room temperature } \\
\text { At room temperature }\end{array}$ \\
\hline
\end{tabular}


values were performed based on ASTM D 3822 with Instron 4411 ( $50 \mathrm{~N}$ load, speed of $10 \mathrm{~mm} / \mathrm{min}$ )resistance device. FTIR analysis of the fibres was performed on Shimadzu 8300 FTIR spectrophotometer (between $4000-400 \mathrm{~cm}^{-1}$ ). The morphology properties were investigated by JEOL JSM-5410 LV operated at $20 \mathrm{kV}$.

\section{RESULTS AND DISCUSSION}

Mechanical properties shows the mechanical change values of Luffa cylindrica fibres after the conventional, microwave and ultrasonic energy method (Fig. 2, Table-5).
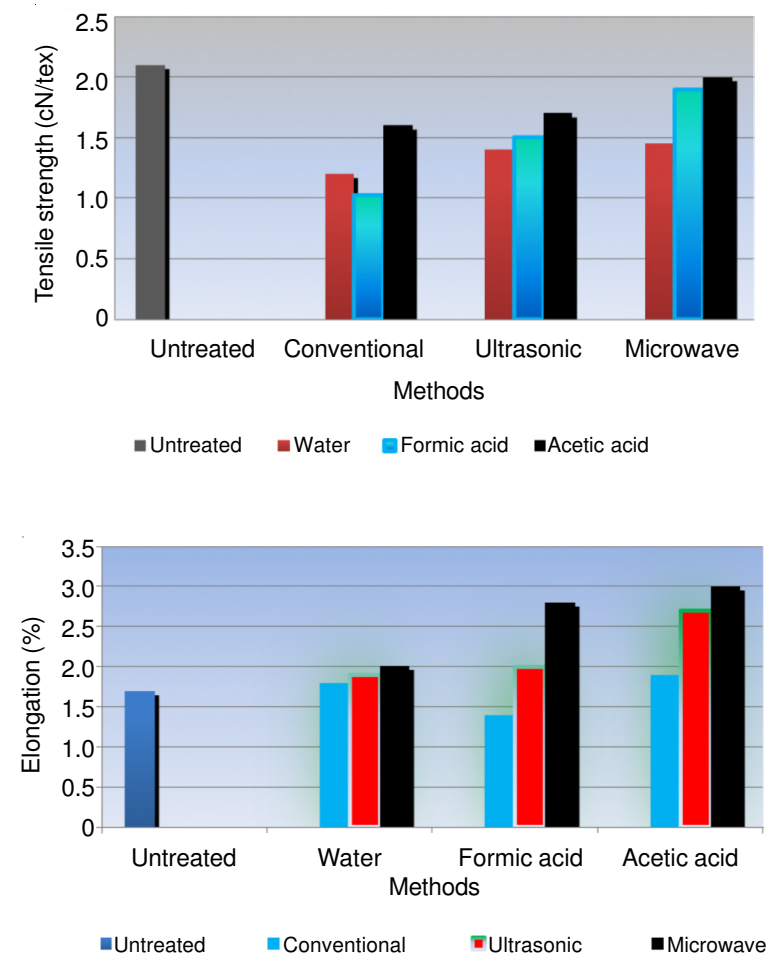

Fig. 2. Mechanical changes in Luffa cylindrica fiber following the chemical treatment

\begin{tabular}{|c|c|}
\hline \multicolumn{2}{|c|}{$\begin{array}{c}\text { TABLE-5 } \\
\text { LUFFA CYLINDRICAL FIBRES WEIGHT } \\
\text { REDUCTION FOR DIFFERENT TREATMENT } \\
\text { CONDITIONS (ROOM TEMPERATURE) }\end{array}$} \\
\hline Processes & Weight reduction $(\%)$ \\
\hline $99 \%$ Formic acid conventional process & 4.30 \\
\hline $100 \%$ Acetic acid conventional process & 3.62 \\
\hline $100 \%$ Formic acid ultrasonic energy process & 8.43 \\
\hline $100 \%$ Acetic acid ultrasonic energy process & 7.20 \\
\hline $99 \%$ Formic acid microwave process & 9.60 \\
\hline $100 \%$ Acetic acid microwave process & 9.20 \\
\hline
\end{tabular}

Conditioned in two different chemical methods and two different processes, after Luffa cylindrica fibres were examined in terms of mechanical characteristics. By comparing the experimental results to bibliographical data obtained with luffa fibers, it is observed that ultrasonic method values given in the literature for the tensile strength and the elongation ${ }^{21,22}$. By comparing the tensile strength, elongation values of untreated fibers with conventional, ultrasonic and micro wave methods in the determination of these parameters and the data scattering. It appears that the chemical treatments (acetylation and formylation) reduce the mechanical properties. It can be explained by considering that waxes, gums, etc. However acetylation and formylation ultrasonic and microwave methods are made with increases mechanical properties. Sonication and acetic acid and formic acid treatments show the surprising high values mechanical properties. This results from the fact that cavitations energy increases the reaction of fibres with the acids. Microwave method, the remarkable increase in mechanical properties. The reason for this as demonstrated that microwave irradiation played a positive role in biomass digestion, it has become desirable to investigate the key operating parameters affecting the pre-treatment so as to optimize the conditions for a further efficient hydrolysis of biomass ${ }^{23}$.

Pre-treatment processes on the decomposition of impurities and natural pigments are generally characterized by weight loss. It is evident from the result that (acetylation and formylation caused weight lost $\mathrm{t}^{21,22}$. However, in ultrasonic method and microwave processes weight loss \% is higher. In the literature studies carried out, Luffa cylindrica fibres loss following the chemical processes is 3-6 $\%^{24}$. The reason for such rates are higher within the applied ultrasonic energy processes due to sonication. However, microwave methods are used for weight loss results are better than ultrasonic methods surface fiber energy more quickly due to transmission surface luffa fiber; uniformity of heating, faster throughputs, fast on and off switching, very high power densities developed in the processing zone, superior moisture levelling.

FT-IR analysis properties: The effectiveness of the acetylation and formylation were confirmed by FT-IR analysis. Fig. 3 shows, the spectra of the raw, Fig. 4 shows Luffa cylindrica fibres ultrasonic energy acetylation chemical application results and Fig. 5 shows Luffa cylindrica fibres microwave energy acetylation chemical application results with FTIR. FT-IR (KBr, disc, $\left.v_{\max }, \mathrm{cm}^{-1}\right): 3560(-\mathrm{OH}), 2920$ (aliphatic strength), 1735 (-C-O ester), 1022 (C-O-C), respectively.

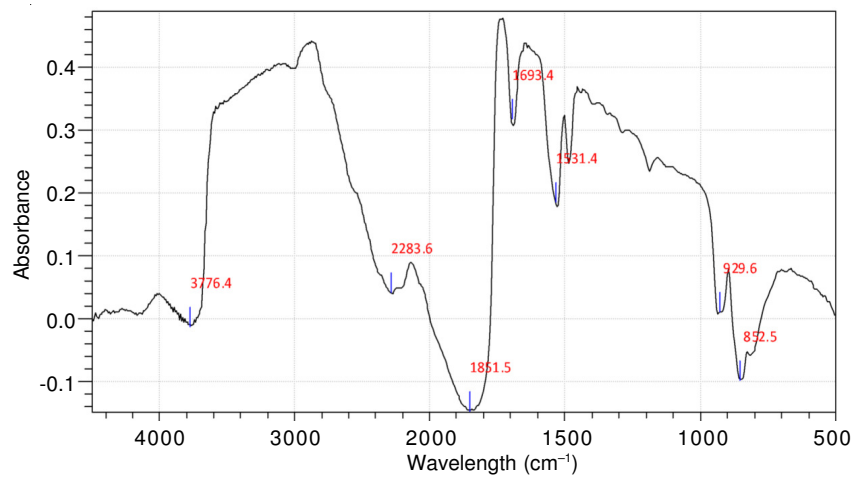

Fig. 3. FTIR spectrum of raw Luffa cylindrica fibres

In the FTIR spectrum of the raw fibre, the bands at 3776 and $1647 \mathrm{~cm}^{-1}$ can be assigned, Figs. 4 and Fig. 5 shows that luffa fibres with acidic acid and formic acid treatment ultrasonic energy signal at 3733-3560 $\mathrm{cm}^{-1}$. Figs. 6 and 7 show FTIR results with ultrasonic energy and microwave energy on fibres FT-IR with a sharp reduction in the signals assigned to the hydroxyls. However, the remaining signal at 3283-3281 $\mathrm{cm}^{-1}$ can be assigned to residual hydroxyl groups, indicating that the acetylation reaction and formyl group were occurred. 


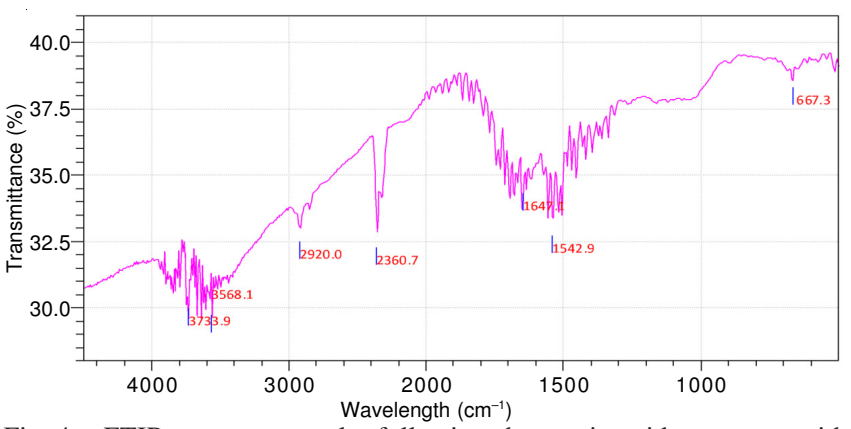

Fig. 4. FTIR spectrum results following the acetic acid treatment with ultrasonic energy

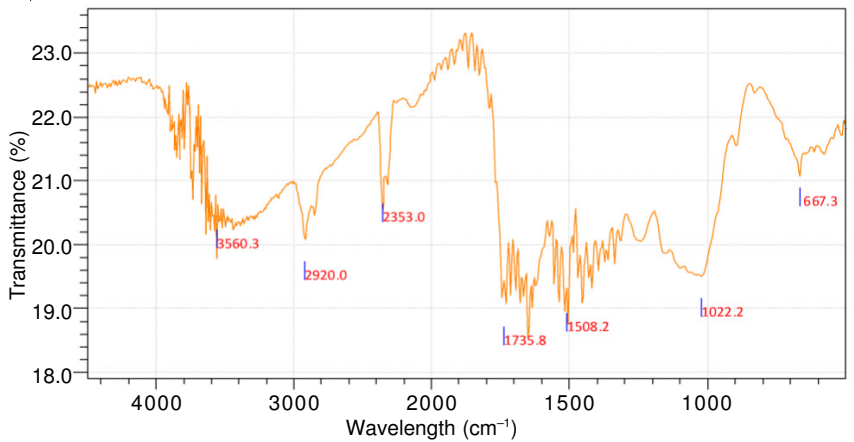

Fig. 5. FTIR spectrum results following the formic acid treatment with ultrasonic energy

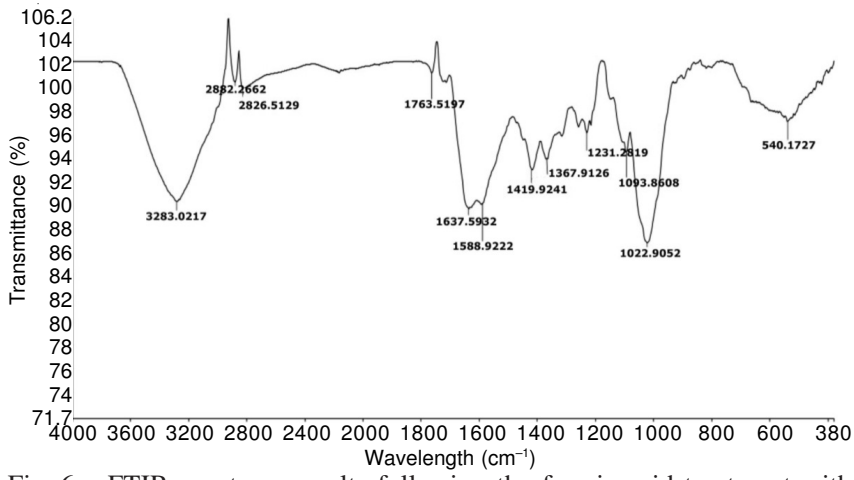

Fig. 6. FTIR spectrum results following the formic acid treatment with microwave energy

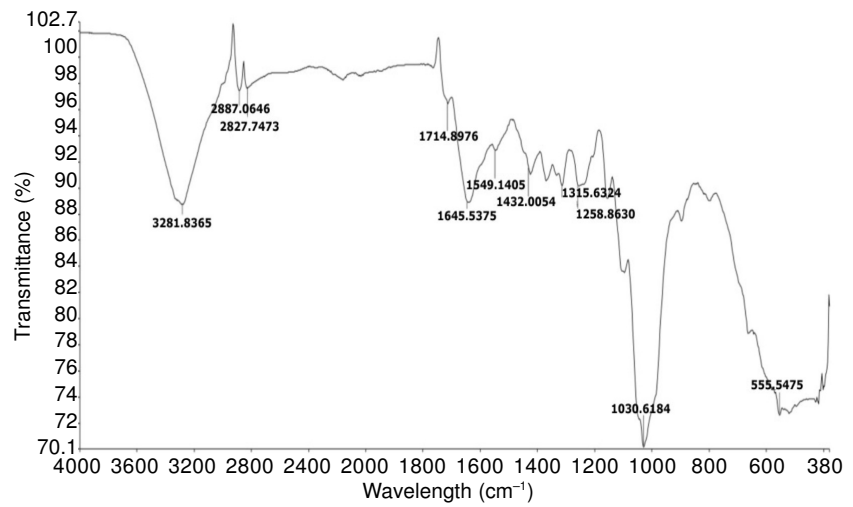

Fig. 7. FTIR spectrum results following the acetic acid treatment with microwave energy

In fact, since no catalysts were used except for acetic acid and formic acid, the acetylation and formyl group reaction occurred preferentially at the easily accessible hydroxyl group on the cell walls of the fibres. Syndication effect is quite high on accelerating the reactions ${ }^{25}$.
The signals at $3568 \mathrm{~cm}^{-1}$ correspond to water adsorbed by the fibre. The sharp signals observed at 1735 and $1647 \mathrm{~cm}^{-1}$ are assigned to a carbonyl from to acetate group and formyl group. The presence of these signals in the spectra of the treated fibres confirms that the acetylation reaction and formyl group reaction were effective. In fact, the partial substitution of the -OH groups on the fibres are interesting, since its hydrophilic character were reduced ${ }^{9}$.

SEM: SEM micrographs of untreated Luffa cylindrica fibres are presented (Figs. 7-13). Figs. 7 and 8 show SEM photographs of fibres treated with formic acid and acetic acid by ultrasonic, microwave, conventional processes. The conventional processes carried out on Flax fibres with formic acid, is known to disclose micro fibres better than those treatments carried out with $\mathrm{NaOH}^{26}$. It is also known that it reveals the macro fibres on the surface of Luffa cylindrica fibres. Following the treatment with formic acid and acetic acid by means of microwave, the outer layers of parenchyma cells have been removed to expose the inner fibres.

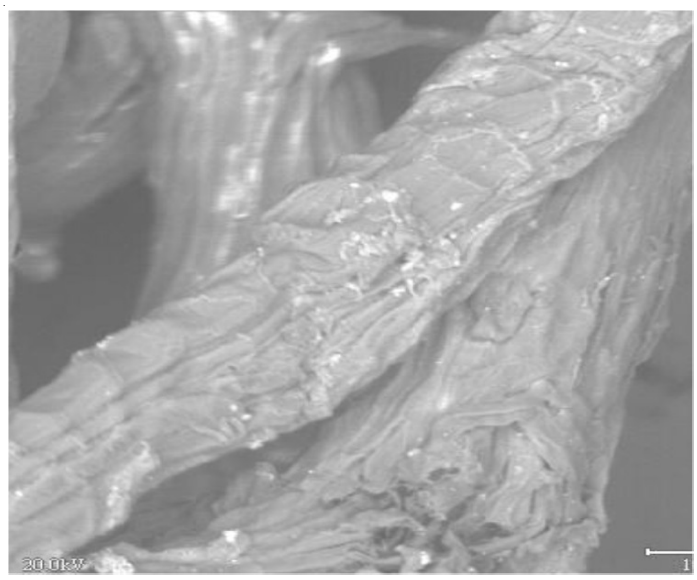

Fig. 8. Untreated Luffa cylindrica fibre

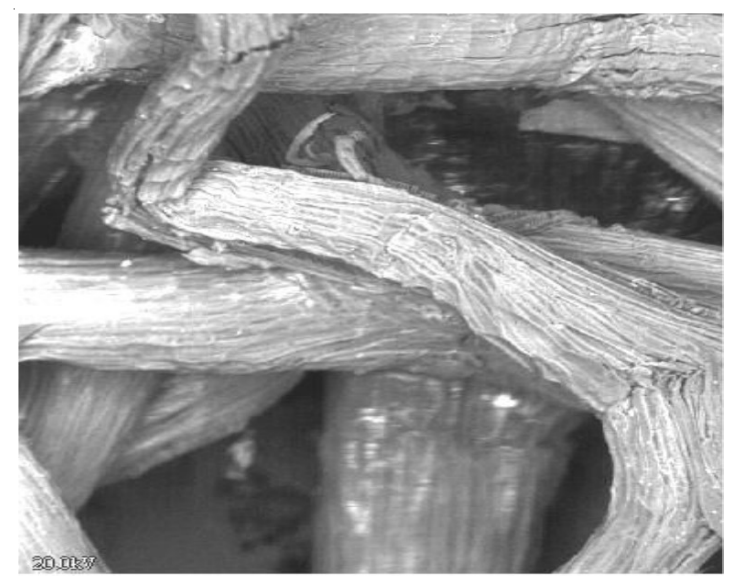

Fig. 9. Treated Luffa cylindrica fibre with acetic acid by ultrasonic energy process

\section{Conclusion}

Two different processes and four different chemical processes, carried out with formic acid and acetic acid were proved to be successful. The reason for the ultrasonic processes to be 


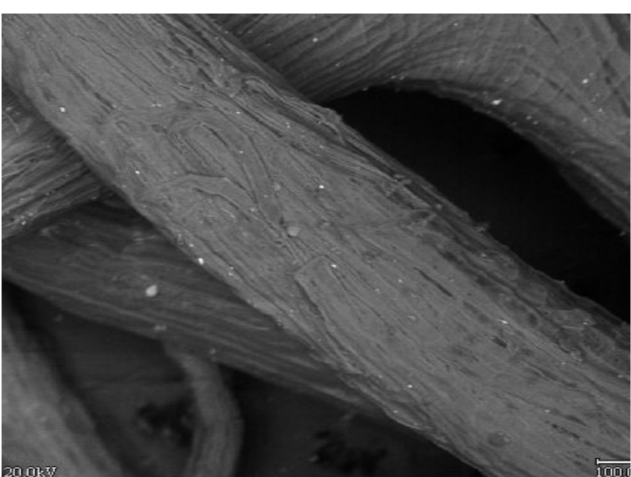

Fig 10. Treated Luffa cylindrica fibre with formic acid by ultrasonic energy process

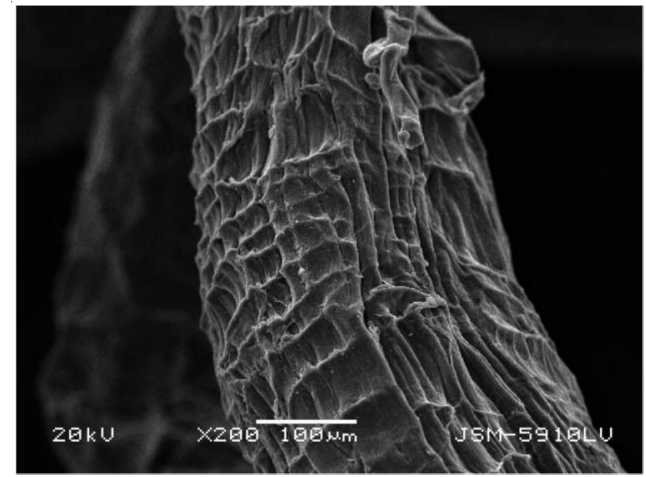

Fig. 11. Treated Luffa cylindrica fibre with formic acid microwave process

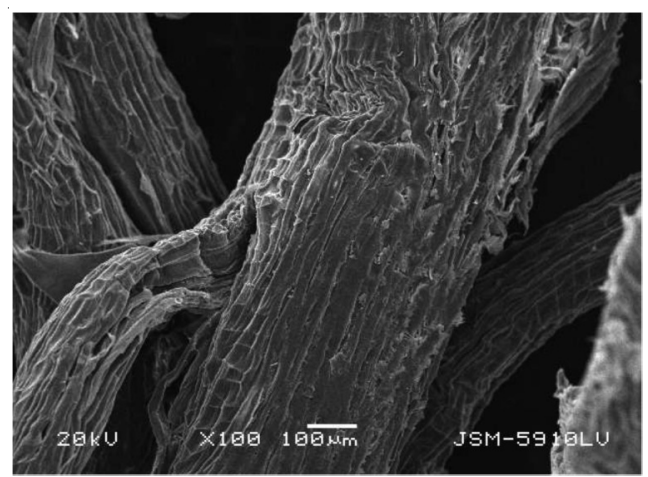

Fig. 12. Treated Luffa cylindrica fibre with acetic acid by microwave process

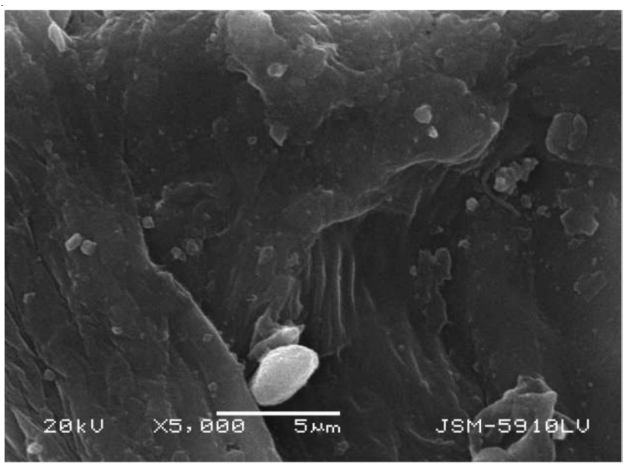

Fig. 13. Treated Luffa cylindrica fibre with acetic acid by microwave process successful is the strength achieved by sonication. The ultrasonic energy process provides both energy and time saving. Microwave power is effective than ultrasonic energy in chemical reactions. Considering all these results; formic acid and acetic acid processes were found to adequately modify the fibres surfaces. In this study, \% weight loss increase is outstanding with the success of ridding the impurities. Weight loss results can be correlated with mechanical test results, which can be treated as a proof for enhanced interfacial interactions with microwave energy better then ultrasonic energy treatment. Beyond the all results, microwave process is clearly provided to saving of chemical substance, energy, water and time.

\section{REFERENCES}

1. A.I.S. Brigida, V.M.A. Calado, L.R.B. Goncalves and M.A.Z. Coelho, Carbohydr. Polym., 79, 832 (2010).

2. N. Reddy and Y. Yang, Trend Biotechnol., 23, 22 (2005).

3. M.K. Rangahau, Luffa-the Sponge Gourd, http://www.crop.cri.nz/ home/productsservices/publications/broadsheets/061luffa.pdf

4. A.L. Leo, R. Rowell and N. Tavares, Sao Carlos, 257 (2000).

5. K. Oksman, Appl. Polym. Sci., 67, 1503 (1998).

6. J.Z. Lu and Q.L. Wu, Wood Sci. Technol., 32, 88 (2000).

7. H.Z. Sharifah and M.P. Ansell, J. Comp. Sci. Technol., 64, 1219 (2004).

8. C.A. Boynard, S.N. Monteiro and J.R.M. Almedia, J. Appl. Polym. Sci., 87, 1927 (2003).

9. A.L.F.S. d'Almeida, D.W. Barreto, V. Calado and J.R.M. d'Almeida, Polym. Polym. Comp., 14, 73 (2006).

10. L.M. Hassan, J. Appl. Polym. Sci., 101, 2495 (2006).

11. N. Merdan, E. Sancak, D. Kocak and M. Yuksek, Asian J. Chem., 24, 975 (2012).

12. E. Oner, I. Baser and K. Acar, J. Soc. Dyers Colorists, 111, 279 (1995).

13. M. Akalin, N. Merdan, D. Kocak and I. Usta, Ultrasonic, 42, 161 (2004).

14. M. Akalin, N. Merdan, D. Kocak and I. Usta, Ultrasonics, 42, 165 (2004).

15. M.J. Delaney, Textile Chem. Colourist, 4, 29 (1972).

16. K. Haggag, H.L. Hana, B.M. Youssef and N.S. El-Shimy, Dyeing Polyester with Microwave Heating Using Disperse Dyestuffs, American Dyestuff Reporter, March, pp. 22-36 (2005).

17. K. Haggag, Fixation of Pad-Dyeing on Cotton Using Microwave Heating, American Dyestuff Reporter, August, pp. 26-30 (1990).

18. K.F. Elgert and C. Hoffmann, Melliand Textilberichte, 3, 174 (1995).

19. S. Soo Kim, S. Gyung Leem, H. Do Ghim, J. Ho Kim and W. Seok Lyoo, Fibers Polym., 4, 204 (2003).

20. A. Ozerdam, I. Tarakcioglu and A. Ozguney, Textile Konfeksiyon, 4, 289 (2008).

21. D.E. Kocak, J. Eng. Mater. Technol., 130, 1 (2008).

22. K. Dilara, J. Polym. Eng., 28, 501 (2008).

23. D.R. Keshwani, J.J. Cheng, J.C. Burns, L. Li and V. Chiang, Microwave Pre-treatment of Switch Grass to Enhance Enzymatic Hydrolysis, In: Proceedings of the ASABE Annual International Meeting, No. 077127.

24. V.O.A. Tanobe, T.H.D. Sydenstricker, M. Munaro and S.C. Amico, Polym. Testing, 24, 474 (2005).

25. D. Fakin, V. Golob, K.S. Kleinschenk and L.M. Marechal, Textile Res. J., 76, 448 (2006).

26. C. Baley, F. Busnel, Y. Grohens and O. Sire, Composite A, 37, 1626 (2006). 